\title{
Induction of parturition in the sow
}

\author{
Partusinductie bij de zeug
}

\author{
${ }^{1,2}$ R. Decaluwe, ${ }^{2}$ G.P.J. Janssens, ${ }^{1}$ I. Declerck, ${ }^{1}$ A. de Kruif, ${ }^{1} D$. Maes \\ ${ }^{1}$ Department of Obstetrics, Reproduction and Herd Health, Faculty of Veterinary Medicine, \\ Ghent University, Salisburylaan 133, B-9820 Merelbeke \\ ${ }^{2}$ Department of Nutrition, Genetics and Ethology, Faculty of Veterinary Medicine, \\ Ghent University, Heidestraat 19, B-9820 Merelbeke \\ ruben.decaluwe@ugent.be
}

\begin{abstract}
Inducing parturition in the sow can be used to improve farrowing supervision, which may lead to more weaned piglets. However, if not applied properly, it may lead to premature delivery. Therefore, induction of parturition should be performed not earlier than two days before the average gestation length of the sows of a farm.

To induce parturition, different protocols, such as single administration of prostaglandins, double administration of prostaglandin with 6-hour interval (split-dose technique) and a combination of prostaglandins and oxytocin $\mathbf{2 4}$ hours later, and different administration routes, such as intramuscular injection in the neck region and injection in the vulvar region, can be used. Other strategies exist but they are less effective and/or less frequently used.

A single injection of prostaglandins results in $60 \%$ of the sows farrowing within working hours (22-32 hours after injection). Using the split-dose technique or the combination of prostaglandins and oxytocin 24 hours later, the percentage increases with $20 \%$. The use of oxytocin however increases the risk of asphyxia in the piglets, especially in case of inappropriate use. Whether farrowing induction should be applied and which protocol used depend on the herd and the preferences of the farmer.
\end{abstract}

\section{SAMENVATTING}

Partusinductie verhoogt het toezicht tijdens het werpen, waardoor het geboortegetal kan toenemen. Wanneer partusinductie echter niet correct wordt toegepast, kan dit leiden tot vroeggeboorte. Daarom mag partusinductie pas ten vroegste twee dagen vóór de gemiddelde drachtduur van de zeugen op een bedrijf worden uitgevoerd.

Voor partusinductie bestaan verschillende protocols, zoals de eenmalige toediening van prostaglandinen, de dubbele toediening van prostaglandinen met zes uur interval (split-dose-techniek) en de combinatie van prostaglandinen met oxytocine 24 uur later en verschillende toedieningswegen, zoals intramusculaire injectie in de nekregio en injectie in de buurt van de vulva. Andere strategieën bestaan maar zijn minder effectief en/of worden minder frequent gebruikt.

$\mathrm{Na}$ een eenmalige injectie van prostaglandinen werpt $60 \%$ van de zeugen binnen de werkuren (22-32 uur na injectie). Met de split-dose-techniek of de combinatie van prostaglandinen en oxytocine 24 uur later is dit $80 \%$. Bij incorrect gebruik is oxytocine echter een risicofactor voor asfyxie bij biggen. Het wel of niet toepassen van partusinductie en welk protocol het beste wordt gebruikt hangen af van het bedrijf en de wensen van de veehouder.

\section{INTRODUCTION}

Induction of parturition is commonly applied in modern sow herds (Vanderhaeghe et al., 2010). It reduces the variation in gestation length and directs parturition towards daytime. As a result, the farrowing process can be supervised more closely, leading to lower rates of stillbirth and neonatal mortality (King et al., 1979; Holyoake et al., 1995; White et al., 1996). Induction of parturition is a useful management tool but if not done properly, it may have negative effects on sow and piglets. Different protocols for farrowing induction have been described. The present paper discusses the use of PGF $2 \alpha$ as a single injection, as a split-dose technique or in combination with oxytocin and other products. Different routes of application (intramuscular, vulvomuscular, intravulvar, peri-anal and topical application on the vulva mucosa) are described. Good knowledge of the different products and schemes with their advantages and their disadvantages is very important, because of the very large financial implications for the farm, in case farrowing induction is not performed properly.

\section{ANATOMY AND PHYSIOLOGY OF PARTURI- TION IN THE SOW}

A normal gestation length in sows takes 114 to 116 days, with $10 \%$ of the sows farrowing before 114 days and $10 \%$ after 116 days of gestation (Vanderhaeghe et 
al., 2010). The parturition process lasts 3 to 5 hours with a piglet being born every 15 to 30 minutes (Oliviero et al., 2010).

The sow has two ovaries and a bicornuate uterus. The length of the different parts of the reproductive tract of non-pregnant sows are given in Table 1. The placenta of the sow is diffuse and epitheliochorial (Frandson et al. 2003a).

The blood vessels of the reproductive tract of the sow are intensively interconnected (Barone et al., 1962; Oxenreider et al., 1965). The most important vein is the utero-ovarian vein which has many anastomoses with the rest of the veins of the genital tract. At the level of the ovaries, there is an arterio-venous plexus (Barone et al., 1962) (Figure 1).

Pregnancy is maintained by high levels of progesterone produced by the corpora lutea which remain the only source of progesterone throughout the entire gestation (Frandson et al., 2003b). Some weeks before parturition, the levels of oestradiol-17 $\beta$ increase and those of progesterone decrease (Robertson and King, 1974). The actual initiation of parturition starts with a signal of the fetus. The adenohypophysis of the fetus produces ACTH (adrenocorticotropic hormone) which initiates the production of glucocorticoids by the adrenal cortex. During gestation, PGF $2 \alpha$ produced by the endometrium is secreted into the uterine lumen due to estradiol secretion by the conceptus (Edgerton et al., 1996). The increase in fetal glucocorticoids redirects the secretion of PGF $2 \alpha$ into the general circulation of the sow. As a result, PGF $2 \alpha$ is transported to different organs. PGF $2 \alpha$ reaches the ovaries, leading to luteolysis and the termination of progesterone production. It also stimulates the release of relaxin from the corpora lutea, the production of oxytocin in the neurohypophysis and uterine smooth muscle contractions (King and Wathes, 1989). Progesterone suppresses the activity of uterine smooth muscles and maintains cervical tone while oxytocin enhances uterine contractions (Frandson et al., 2003b). It is clear that PGF2 $\alpha$ plays a central role in the parturition process.

\section{FARROWING INDUCTION: ADVANTAGES AND DISADVANTAGES}

Thirty percent of pig farmers in Flanders frequently apply induction of parturition (Vanderhaeghe et al.,

Table 1. Length $(\mathrm{cm})$ of the different parts of the reproductive tract of non-pregnant sows (Frandson et al., 2003).

\begin{tabular}{ll}
\hline Part of the reproductive tract & Length (cm) \\
\hline Oviduct & $15-30$ \\
Uterus & \\
Horn & $40-65$ \\
Body & 5 \\
Vagina & $10-15$ \\
Vestibulum & $6-8$ \\
\hline
\end{tabular}

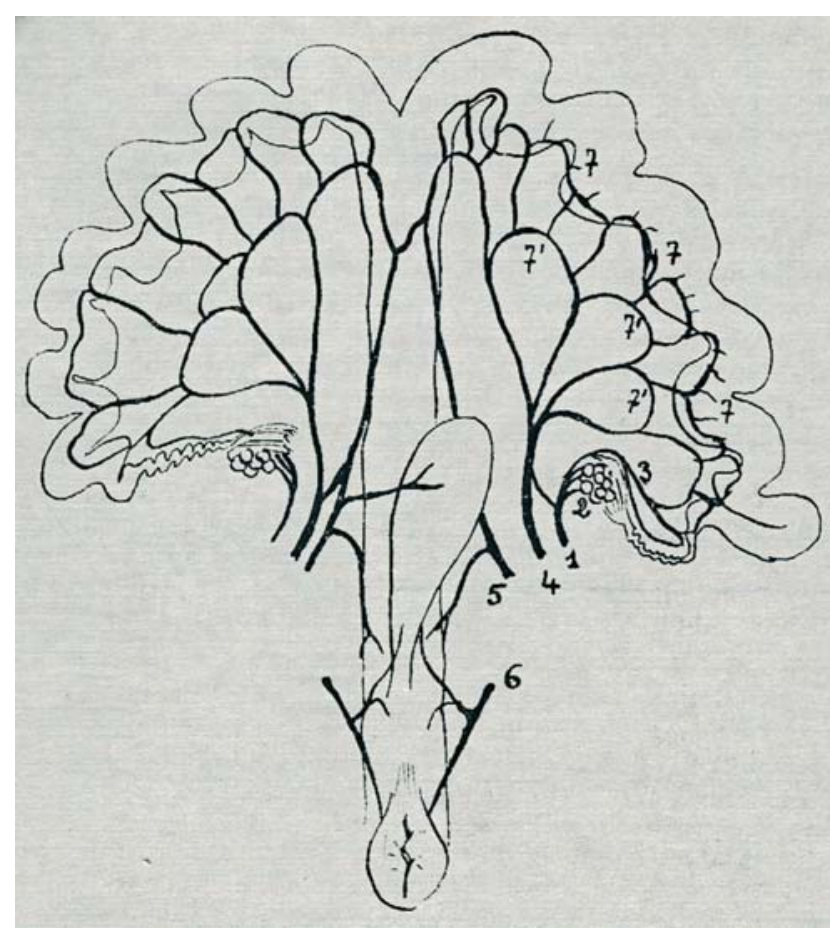

Figure 1. Scheme of the veins of the genital tract of the sow (adapted from Barone et al., 1962). 1.Utero-ovarian vein, 2. Ovarian vein, 3. Tubo-ovarian vein, 4 . Uterine vein, 5 . Vaginal vein, 6 . Internal pudendal vein, 7 . Veneus arches

2010). Reasons for this practice are numerous, but the main ones include reducing the variability of gestation length and directing parturition towards daytime (normal working hours), which facilitates close supervision during parturition (King et al., 1979). Parturition is a stressful event for the sow as well as for the piglets. For the latter, it may be a life-threatening situation (van Rens and van der Lende, 2004). Close supervision of the farrowing process generally leads to less stillborn piglets and lower neonatal piglet mortality (Holyoake et al., 1995; White et al., 1996). Both conditions are largely caused by asphyxia during parturition (Herpin et al., 1996; van Rens and van der Lende, 2004). A long duration of the expulsive phase is a major risk factor for intrapartum asphyxia (Herpin et al., 1996). Therefore, minimizing the duration of parturition, for instance by induction of parturition using oxytocin, could be beneficial (van Dijk et al., 2005; Mota-Rojas et al., 2002). Other studies however, do not report this result (Cassar et al., 2004, Wherend et al., 2005, Kaeoket, 2006). More intensive supervision of the farrowing process also allows to transfer piglets of the same age from one sow to another more easily and to apply routine interventions, such as iron injection, teeth and tail clipping, and castration of piglets of the same age (King et al., 1979). Additionally, a small variation in farrowing time fits better into the strict time schedule of sow batch-management systems. Pigs can be weaned in time allowing sufficient time for hygienic measures. If the insemination period of a group of sows takes three days and the gestation length takes 113-118 days, the day of the earliest and latest partu- 
Table 2. Gestation length and treatment rate of the neonatal piglet when induction of parturition was performed using the split-dose technique via injection in the abdominal muscles (AB), via vulvar injection (VM) or when no induction was performed (Control) (Gunvaldsen et al., 2007).

\begin{tabular}{llll}
\hline & Control & AB & VM \\
\hline Gestation length & $117.0 \pm 1.4^{\mathrm{a}}$ & $115.1 \pm 1.4^{\mathrm{b}}$ & $115.1 \pm 0.22^{\mathrm{b}}$ \\
Piglet treatment rate (\%) & $8.3 \pm 11.0^{\mathrm{a}}$ & $16.1 \pm 23.0^{\mathrm{b}}$ & $16.3 \pm 21.5^{\mathrm{b}}$ \\
\hline
\end{tabular}

rition may differ seven days, which makes supervision difficult. With induction of parturition, this distribution may be narrowed.

If farrowing induction is not done properly, it may lead to premature delivery of piglets. Such piglets have a high risk of dying, they have a lower birth weight and a lower growth during the first three weeks of age (King et al., 1979; Gunvaldsen et al., 2007). When birth is induced before day 114 of gestation, the incidence of neonatal mortality and of spleyleg is higher (Friendship et al., 1990; Sellier et al., 1999). Piglets delivered by sows in which parturition was induced, have a two times higher odds of needing treatment for disease (Gunvaldsen et al., 2007) (Table 2).

Farrowing induction before day 112 of gestation is associated with a lower percentage of fat, protein and globulin in colostrum (Jackson et al., 1995; Walkiewicz et al., 2006). When induced at day 113 of gestation, Foisnet et al. (2011) reported higher lactose, lower ash and protein and equal concentrations of immunoglobulin $\mathrm{G}$ in colostrum compared to the non-induced control group.

\section{INDUCTION OF PARTURITION IN A HERD: FAC- TORS TO BEAR IN MIND}

The natural gestation length in sows is 114-116 days. Inducing parturition at day 114 should be no problem because all sows farrow at the normal average gestation length. Unfortunately, on herd level, this is often not the case. Breed, follicular development, ovulation rate and litter size, prenatal maternal stress and nutritional status of the dam are factors that influence fetal development and thus maturity at a certain gestation length (Vonnahme et al., 2002; Vinsky et al., 2006; Town et al., 2005; Tuscherer et al., 2002; Vinsky et al., 2006). Gunvaldsen et al. (2007) induced parturition in sows at day 114 of gestation and observed negative effects on piglet performance compared with the control group that had a gestation length of 117 days. The optimal time to induce parturition may therefore differ from farm to farm. Kirkwood et al. (1999) recommended that induction of parturition should not be performed more than two days before the average gestation length of the sows of a farm. Farrowing induction is especially recommended or interesting in herds suffering from specific problems, such as too many stillborn piglets, the need for organization of the batch system and the possibility to exploit the benefits to the maximum (e.g. maximize quantity and quality of farrowing supervision). When there is no reason or no possibility to use these advantages, the benefits of partus induction are doubtful. The benefits obtained by induction cannot be attributed to the injection as such, but to an optimized parturition management.

The goals of induction of parturition (e.g. reducing stillborn piglets versus no weekend-farrowings) may differ between herds. The most preferable induction protocol is herd-specific.

\section{DIFFERENT PRODUCTS AND SCHEMES FOR THE INDUCTION OF PARTURITION}

\section{The use of PGF $2 \alpha$ in inducing parturition}

\section{Types of $P G F 2 \alpha$}

Prostaglandins may be divided into two main categories: products that are chemically identical to uterine-derived PGF $2 \alpha$ and products that are chemically identical to its agonist, sodium cloprostenol. Cloprostenol is available in a racemic mixture and with the D-isomer alone. The latter is approximately 10fold more potent than the racemic mixture. Cloprostenol has a greater affinity for the PGF2 $\alpha$ receptor and has a longer half-life than PGF $2 \alpha$ ( 3 hours versus a few minutes), but it is not clear if this results in a better luteolytic effect (De Rensis et al., 2011). In cows, it has been shown that cloprostenol increases uterine contractions more than natural PGF2 $\alpha$ (Hirsbrunner et al., 1998). However, this has not been investigated in sows yet. Prostaglandins are cleared by one or two passages through the lungs and liver (de Rensis et al., 2011).

PGF2 $\alpha$ as well as cloprostenol influence prepartum behavior in sows. When farrowing occurs without induction, prepartum activity is mainly seen during the last 16 hours before the onset of parturition. When PGF2 $\alpha$ is applied, an immediate increase in prepartum activity is seen for a few hours, followed by an inactive period, followed by a second wave of activity during the last 10 hours prior to parturition. The use of cloprostenol increases prepartum activity to a moderate level from two hours after injection until parturition (Widowski et al., 1990).

Prostaglandins are absorbed very quickly through the skin. Pregnant women (risk of abortion) and persons with asthma or other chronic respiratory disorders (risk of tachypnea and constriction of smooth muscle cells) should avoid the use of these products (Straw et al., 2008). 


\section{Methods of application}

In the following, the term working hours will be used frequently. It refers to the normal working hours performed by the farmer. They will be expressed in relation to the time of the first injection for partus induction. The time frame slightly differs between studies but mostly, a period of 22-32 hours after the first injection is used, meaning that a day of work lasts for 10 hours.

\section{Single intramuscular injection}

Several studies have shown that with one intramuscular injection of prostaglandin, 50 to $60 \%$ of the sows start farrowing between 22 and 32 hours (= working hours) after injection (Kirkwood et al., 1996; Kirkwood et al., 1998; Alexopoulos et al., 1998) (Table 3 ). The proportion of sows farrowing during daytime is therefore too low. Alternatives with a higher predictability are necessary.

\section{Single application via alternative routes}

Routes of application are intra- and perivulvar injection, topical application at the vulvar mucosa and injection in the peri-anal region (Friendship et al., 1990, De Rensis et al., 2002, Kaeoket et al., 2006; Straw et al., 2008; Straw et al., 2008; Kirkwood et al., 1996).

When PGF $2 \alpha$ is injected in the region of the vulva, it may reach the ovaries in two ways (Figure 2). The first way is via a systemic route with a passage through the lungs (Ginther, 1976). Because PGF2 $\alpha$ is metabolized in the lungs, the resulting concentrations at the ovaries are relatively low and probably comparable to the achieved concentrations when an intramuscular injection is given, because the same systemic route is followed (De Rensis et al., 2011; Ginther et al., 1976).

Secondly, the product may reach the ovarian plexus through the utero-ovarian vein, where a counter-current mechanism allows high concentrations of the product at the level of the ovary (Barone et al., 1962; Oxenreider et al., 1965; Ginther, 1976; de Rensis et al., 2011). Even by injecting a small dosage in the region of the vulva, a relatively high concentration of PGF2 $\alpha$ may reach the ovaries (Kirkwood et al., 1996).

Intra- and perivulvar injection of half the dosage prostaglandin results in the same percentage of sows farrowing during working hours compared with sows given an intramuscular application of the total recommended dosage (Friendship et al., 1990; Kirkwood et al., 1996; Kaeoket et al., 2006). Independent of the dosage, the percentage of sows farrowing during working hours after injection in the peri-anal region is lower than after the administration in the vulvomuscular region (Kirkwood et al., 1996). Specific data can be found in Table 3.

Straw et al. (2008) investigated the use of the topical administration of PGF $2 \alpha$. They applied $50 \%$ of the recommended intramuscular dose either topical onto the vulvar mucosa or via vulvar injection. The percentage of sows farrowing during working hours after topical administration was significantly lower than after vulvar injection.

Intravulvar injection of half a dosage of prostaglandin reduces the cost and the nestbuilding behavior but it does not improve the predictability of farrowing compared to a single intramuscular injection (Friendship et al., 1990). In Belgium, the application of prostaglandin via another route than intramuscular injection is currently off-label.

\section{Split-dose technique}

Some sows might not respond to a single injection with prostaglandin due to incomplete luteolysis. Some of the corpora lutea recover and pregnancy is maintained (De Rensis et al., 2011). In sheep, it has been shown that pulsatile concentrations of PGF $2 \alpha$ increase the luteolytic effect. Assuming this is the same for pigs, multiple injections should decrease the risk of incomplete luteolysis (Kirkwood et al., 1999; De Rensis et al., 2011). This method is called the split-dose technique: two doses of prostaglandin are applied with an interval of six hours.

A significant increase in parturition during the working hours is observed in sows when the split-dose technique is applied intramuscularly compared with a single intramuscular injection $(87.5 \%$ versus $61.0 \%)$ (Kirkwood et al., 1998) (Table 3).

As for the single injection with PGF2 $\alpha$, different application routes for the split-dose technique are possible. When this technique is applied with half the dosage by intravulvar injection, the percentage of sows

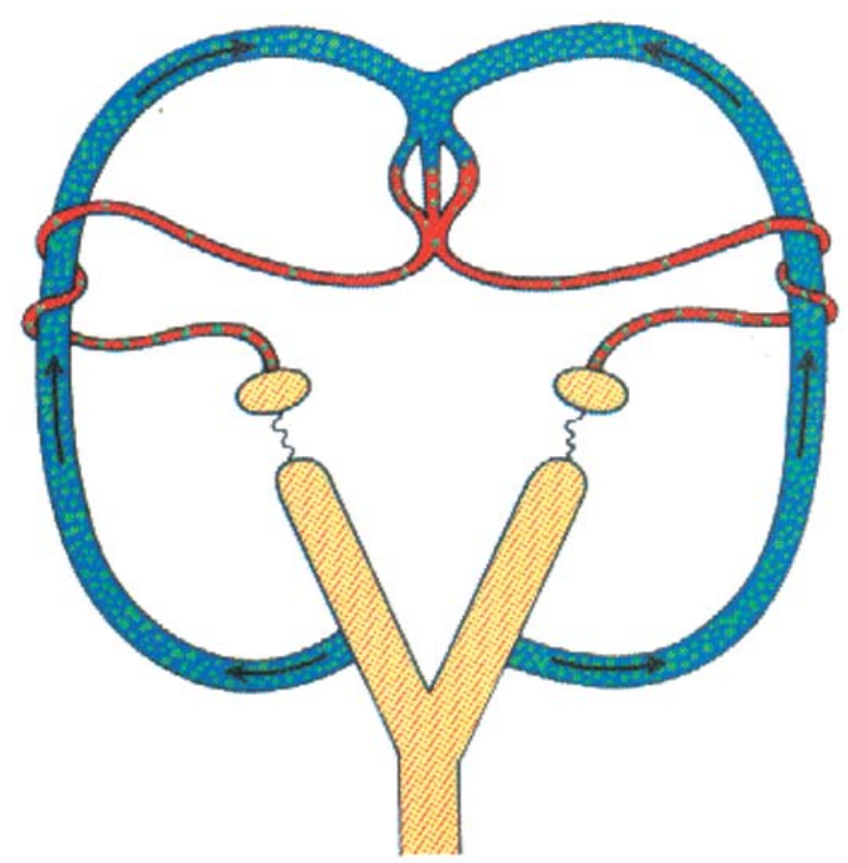

Figure 2. Schematic representation of the systemic and local utero-ovarian pathways (adapted from Ginther, 1976). 


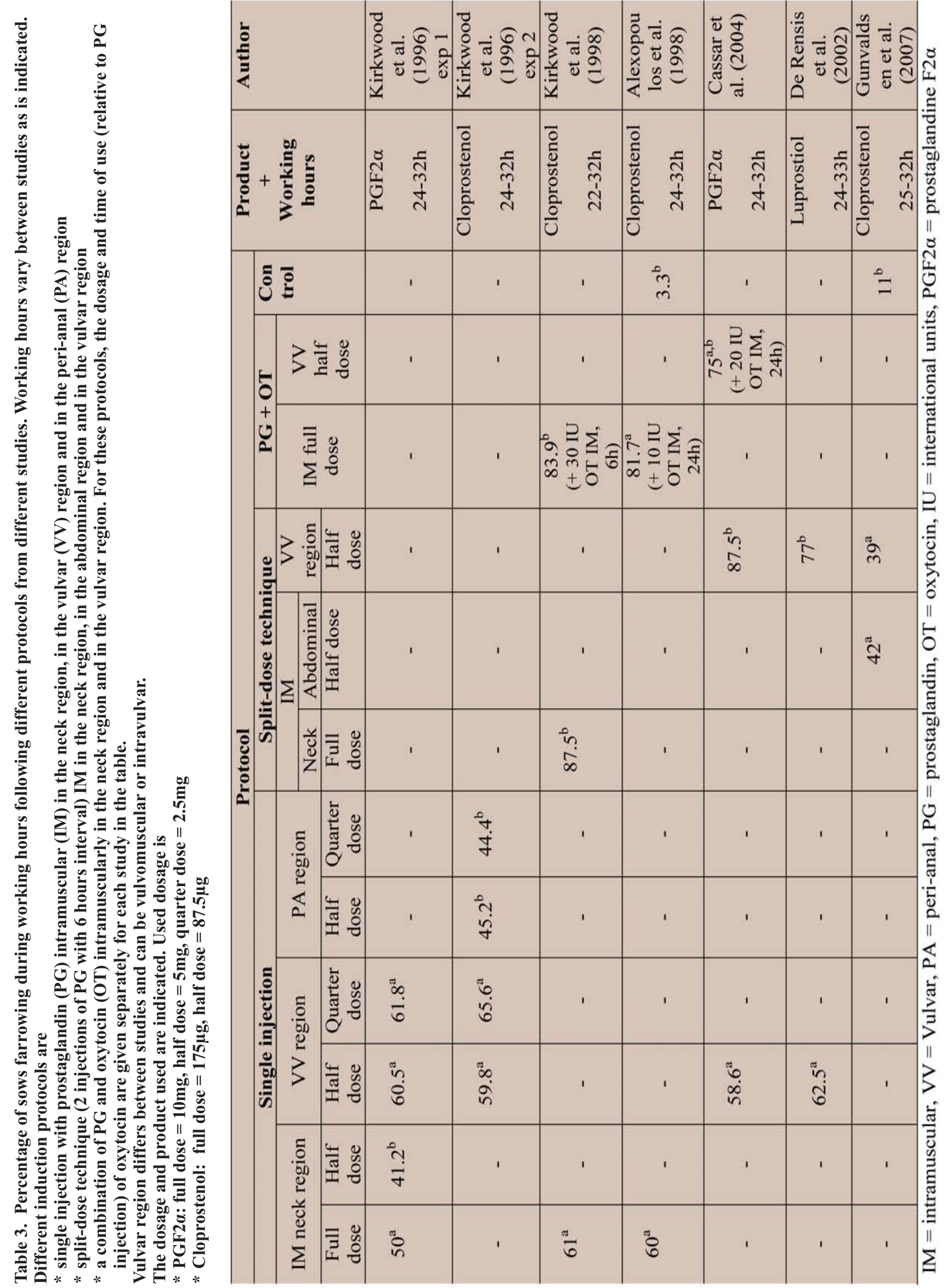


farrowing during working hours increases significantly, up to $87.5 \%$ (De Rensis et al., 2002; Cassar et al., 2004) (Table 3). These percentages are comparable to the split-dose administered intramuscularly with the full dosage (Kirkwood et al., 1998).

Gunvaldsen et al. (2007) compared injection into the external abdominal oblique muscle with vulvar injection as alternative application routes for the splitdose technique using half the dosage of PGF2 $\alpha$. Approximately $40 \%$ of the sows of each group farrowed during working hours (Table 3). Nonetheless, this percentage is quite low compared with the results of other studies applying the split-dose technique. In each group, approximately $50 \%$ of the sows farrowed 8-24 hours after the first injection while in the control group (with administration of saline) only $14 \%$ of the sows farrowed before 32 hours after injection (De Rensis et al., 2002; Cassar et al., 2004; Gunvaldsen et al., 2007). This indicates that both techniques are equally effective. The shorter time interval chosen as working hours (25-32 hours after the first injection) in this study might have influenced the percentage of sows farrowing in each time interval.

The split-dose technique by topical use on the vulvar mucosa with half of the dose PGF $2 \alpha$ provided similar results as with intravulvar injection, unlike the single topical application (Straw et al., 2008). These data show that when the split-dose technique is used, on average $77-87 \%$ of the sows farrow during the next working day compared with $60 \%$ of the sows receiving a single injection (Table 3 ). As a result, it is easier to increase farrowing supervision and optimize parturition management. In Belgium, the split-dose technique is currently off-label use of prostaglandin.

\section{The use of other products for the induction of par- turition}

Apart from prostaglandins, numerous products have been studied to improve partus induction. However, these products are always used in combination with PGF $2 \alpha$ or its analogues.

\section{The use of oxytocin in combination with prostaglandin}

In comparison with a single injection of cloprostenol, combining an injection of cloprostenol with an injection of oxytocin 6 hours or 24 hours later increased the percentage of sows farrowing during working hours with more than 20\% (Kirkwood et al., 1998; Alexopoulos et al., 1998) (Table 3). This technique seems to improve the predictability of parturition onset.

The effect of the time between the administration of prostaglandin and oxytocin on the percentage of sows farrowing within working hours is limited. Kirkwood et al. (1999) stated that the physiological response to oxytocin depends on the proximity to the natural onset of farrowing. Nonetheless, time and dosage of oxytocin may have an impact on other important factors.

The ultimate goal of partus induction is increasing the number of weaned piglets without (much) extra labor. Decreasing the number of stillborn piglets plays a major role in this objective. Birth of the piglets may only start when the cervix is relaxed and dilated. The physiological mechanisms that prevent the onset of parturition before cervix relaxation may be disturbed by exogenous oxytocin administration. In this way, the piglets will be pushed against a closed cervix, which is clearly not desirable. When prostaglandins are used, the time of complete relaxation of the cervix ( $=$ the time when oxytocin may be used) is not exactly known and may differ between sows (Gilbert et al., 1999). Some authors concluded that oxytocin (10 - 30IU) increases the percentage of stillborn piglets (Yang et al., 1996; Alexopoulos et al., 1998; Cassar et al., 2005). Mota-Rojas et al. (2005) found that the use of oxytocin increases the frequency, intensity and duration of myometrial contractions leading to more bradycardia in piglets, more piglets that are covered with meconium, more aberrant umbilical cords and more intrapartum mortality. Other studies showed no negative effects of oxytocin $(10-30 \mathrm{IU})$ on these parameters (Kirkwood et al., 1998; Wehrend et al., 2005; Kaeoket et al., 2006). This may by explained by differences in time needed for a full relaxation of the cervix after the induction with prostaglandins (Gilbert et al., 1999). The administration of high doses of oxytocin may induce hard pressure upon the piglets and their umbilical cord, which leads to hypoxia (Mota-Rojas et al., 2005). It may also lead to fatigue of the uterus and a decreased reaction on physiological concentrations of oxytocin (Gilbert et al., 1999). The contradictory results concerning optimal timing and dosage of oxytocin warrants further research.

Next to a major cause of intrapartum mortality, asphyxia is also a risk factor for neonatal mortality and mortality until 10 days of age. It also leads to reduced postnatal growth (Herpin et al., 1996; Taverne and van der Weijden, 2008).

The use of other products in combination with prostaglandin

The administration of relaxin 24 hours before injection with PGF2 $\alpha$ enhances the synchrony of the onset of parturition. Suggested hypotheses are sensitization of the uterus to the withdrawal of progesterone and the well-known effects of relaxin on cervical dilatation (Butler and Boyd, 1983). However, relaxin is not commercially available in Belgium.

The use of a $\beta$-adrenergic blocking agent, e.g. carazolol, 20 hours after PGF2 $\alpha$ results in the prompt onset of labor, comparable to the effects of oxytocin but without negative effects on the piglets. The binding to the myometrial adrenergic receptors is assumed to inhibit the tocolytic effects of adrenaline released in response to the pain and discomfort of parturition (Holtz et al., 1990).

The contraction of the myometrium may not only be induced by oxytocin but also by $\alpha 2$-agonists. The use of such products 20 hours after the administration 
of PGF $2 \alpha$, results in most sows starting to farrow two hours later. Xylazin is the best-known $\alpha 2$-agonist but this product causes sedation and vomiting, which is not desirable in sows around parturition (Yang et al., 1996).

Corticosteroids have also been tested for their applicability to induce parturition. Periparturient cortisol plays an important role in the maturation of different fetal tissues and the accumulation of glycogen (Fowden et al., 1985). Inducing parturition may alter the dynamics of the periparturient cortisol surge (Gunvaldsen et al., 2007). When corticosteroids are used in the induction protocol, time to the onset of farrowing is not influenced (De Rensis et al., 2002; Cassar et al., 2005). De Rensis et al. (2002) reported a lower birth weight but a higher piglet growth during the first three days after parturition. However, this was not observed by Cassar et al. (2005). A lower neonatal mortality was seen when corticosteroids were used (Bilkei et al., 1991).

\section{DISCUSSION AND CONCLUSIONS}

A single injection of prostaglandins, the split-dose technique and a combination of prostaglandin with the administration of oxytocin 24 hours later are the three main protocols used to induce parturition. Mostly, intramuscular injection in the neck region and injection in the vulvar region are used. In the latter, half the dose is sufficient to obtain the same results as the full dose used intramuscularly. With a single injection of prostaglandins, only $60 \%$ of the sows farrow within working hours. The possibility of intensive supervision during parturition remains rather low. Both the split-dose technique and the combination of prostaglandin and oxytocin applied 20-24 hours later, increase the percentage of sows farrowing during working hours up to $85 \%$. The use of oxytocin may have negative effects, mainly due to increasing asphyxia in piglets but the literature is ambiguous. The timing and correct dosing of oxytocin administration are critical factors but exact guidelines cannot be given.

The benefits obtained by the induction of parturition are not a result of the injection as such but of an optimized parturition management. Induction of parturition is especially interesting in cases where increased management at farrowing may help to solve the herd problem. However, it is important that the induction is not given too early in gestation. Gestation length differs between farms and induction should be performed not earlier than two days before the average gestation length of the farm.

In conclusion, the ideal induction protocol is herdspecific as the purpose may differ between herds. Inducing parturition is merely a tool to optimize parturition management and should be used two days before the average gestation length of the farm at the earliest.

\section{LITERATURE}

Alexopoulos C., Saratsis Ph., Samouilidis S., Saoulidis K., Brozos Ch., Kyriakis SC. (1998). The Effect of Cloprostenol Alone or with oxytocin on induction of parturition, litter characteristics and subsequent fertility of the sow. Reproduction in Domestic Animals 33, 83-88.

Barone R., Pavaux C. Frapart P. (1962). Les vaisseaux sanguins de l'appareil génital chez la truie. Bulletin de la Société des Sciences Vétérinaires et de Médecine comparée de Lyon 64 (3), 337-346.

Bilkei G. (1991). Effect of antepartum administration of prednisolone on the early postnatal mortality of piglets in relation to the body condition of the sow. Tierärztliche Praxis 19 (2), 147-150.

Butler W.R., Boyd R.D. (1983). Relaxin enhances synchronization of parturition induced with prostaglandin $\mathrm{f}_{2 \alpha}$ in swine. Biology of Reproduction 28, 1061-1065.

Cassar G., Kirkwood R.N., Friendship R., Poljak Z. (2005). Sow and litter performance following farrowing induction with prostaglandin: Effect of adjunct treatments with dexamethasone or oxytocin. Journal of Swine Health and Production 13 (2), 81-85.

De Rensis F., Saleri R., Tummaruk P., Techakumphu M., Kirkwood R.N. (2011). Prostaglandin F2 $\alpha$ and control of reproduction in female swine: a review. Theriogenology in press

De Rensis F., Sottocorona M., Kirkwood R.N. (2002). Effect of prostaglandin and dexamethasone injection on farrowing and piglet neonatal growth. Veterinary Record 151, 330-331.

Edgerton L.A., Kaminski M.A., Silvia W.J. (1996). Changes in uterine secretion of prostaglandin $\mathrm{F}_{2 \alpha}$ in response to oxytocin during the estrous cycle, early pregnancy and estrogen-induced pseudopregnancy in swine. Biology of Reproduction 55, 657-662.

Ellendorf F., Taverne M., Elsaesser F., Forsling M., Parvizi N., Naaktgeboren C., Smidt D. (1979). Endocrinology of parturition in the pig. Animal Reproduction Science 2 (13), 323-334.

Foisnet A., Farmer C., David C., Quesnel H. (2011). Farrowing induction induces transient alterations in prolactin concentrations and colostrum composition in primiparous sows. Journal of Animal Science 89 (10), 3048-3059.

Fowden A.L., Comline R.S., Silver M. (1985). The effect of cortisol on the concentration of glycogen in different tissues in the chronically catheterized fetal pig. Quarterly Journal of Experimental Physiology 70, 23-35.

Frandson R.D., Wilke W.L., Fails A.D. (2003a). Anatomy of the female reproductive system. In: Frandson R.D. (editors). Anatomy and Physiology of Farm Animals . $6^{\text {th }}$ Ed., Blackwell Publishing, Iowa, p. 387-394.

Frandson R.D., Wilke W.L., Fails A.D. (2003b). Pregnancy and parturition. In: Frandson R.D. (editors). Anatomy and Physiology of Farm Animals. $6^{\text {th }}$ Ed., Blackwell Publishing, Iowa, p. 405-414.

Friendship R.M., Templeton C.L., Deckert A.E. (1990). An evaluation of vulvomucosal injections of prostaglandins for induction of parturition in swine. The Canadian Veterinary Journal 31, 433-436.

Gilbert C.L. (1999). Oxytocin secretion and management of parturition in the pig. Reproduction in Domestic Animals 34, 193-200.

Ginther O.J. (1976). Comparative anatomy of uteroovarian vasculature. Veterinary Scope 1, 2-17. 
Gunvaldsen R.E., Waldner C., Harding J.C. (2007). Effects of farrowing induction on suckling piglet performance. Journal of Swine Health and Production 15 (2), 84-91.

Herpin P., Le Dividich J., Hulin J.C., Fillaut M., De Marco F., Bertin R. (1996). Effects of the level of asphyxia during delivery on viability at birth and early postnatal vitality of newborn pigs. Journal of Animal Science 74, 2067-2075.

Hirsbrunner G., Küpfer U., Burkhardt H., Steiner A. (1998). Effect of different prostaglandins on intrauterine pressure and uterine motility during diestrus in experimental cows. Theriogenology 50, 445-455.

Holtz W., Schmidt-Baulain R., Meyer H. Welp C. (1990). Control of prostaglandin-induced parturition in sows by injection of the beta-adrenergic blocking agent carazolol or carazolol and oxytocin. Journal of Animal Science 68, 3967-3971.

Holyoake P.K., Dial G.D., Trigg T., King V.L. (1995). Reducing pig mortality through supervision during the perinatal period. Journal of Animal Science 73, 3543-3551.

Jackson J.R., Hurley W.L., Easter R.A., Jensen A.H., Odle J. (1995). Effects of induced or delayed parturition and supplemental dietary fat on colostrum and milk composition in sows. Journal of Animal Science 73, 1906-1913.

Kaeoket K. (2006). The Effect of dose and route of administration of r-cloprostenol on the parturient response of sows. Reproduction in Domestic Animals 41, 472-476.

King G.J., Robertson H.A., Elliot J.I. (1979). Induced parturition in swine herds. The Canadian Veterinary Journal 20, 157-160.

King G.J., Wathes D.C. (1989). Relaxin, progesterone and estrogen profiles in sow plasma during natural and induced parturitions. Animal Reproduction Science 20, 213220.

Kirkwood R.N. (1999). Pharmacological intervention in swine reproduction. Swine Health and Production 7 (1), 29-35.

Kirkwood R.N., Aherne F.X. (1998). Increasing the predictability of cloprostenol-induced farrowing in sows. Swine Health and Production 6 (2), 57-59.

Kirkwood R.N., Thacker P.A., Aherne F.X., Goonewardene L.A. (1996). Swine Health and Production 4 (3), 123-126.

Mota-Rojas D., Martínez-Burnes J., Trujillo M.E., López A., Rosales A.M., Ramírez R., Orozco H., Merino A., Alonso-Splibury M. (2005). Uterine and fetal asphyxia monitoring in parturient sows treated with oxytocin. Animal Reproduction Science 86, 131-141.

Oliviero C., Heinonen M., Valros A., Peltoniemi O. (2010). Environmental and sow-related factors affecting the duration of farrowing. Animal Reproduction Science 119, 85-91.

Oxenreider S.L., McClure R.C., Day B.N. (1965). Arteries and veins of the internal genitalia of female swine. Journal of Reproduction and Fertility 9, 19-27.

Robertson H.A., King G.J. (1974). Plasma concentrations of progesterone, oestrone, oestradiol-17 $\beta$ nd of oestrone sulphate in the pig at implantation, during pregnancy and at parturition. Journal of Reproduction and Fertility 40, 133-141.

Sellier P., Dando E., Dando P. (1999). Induction of parturition in the sow and incidence of splayleg syndrome in the newborn piglet (1999). Annales de Zootechnie 48 (3), 153-161.

Straw B., Bates R., May G. (2008). Influence of method of administration of prostaglandin on farrowing and relati- onship between gestation length and piglet performance. Journal of Swine Health and Production 16 (3), 138-143.

Taverne M.A.M., van der Weijden G.C. (2008). Parturition in domestic animals: Targets for future research. Reproduction in Domestic Animals 43 (5), 36-42.

Town S.C., Patterson J.L., Pereira C.Z., Gourley G. Foxcroft G.R. (2005). Embryonic and fetal development in a commercial dam-line genotype. Animal Reproduction Science 85, 301-316.

Tuscherer M., Kanitz E., Otten W., Tuscherer A. (2002). Effects of prenatal stress on cellular and humoral immune responses in neonatal pigs. Physiology \& Behavior 63 (3), 195-203.

Van Dijk A.J., van Rens B.T.T.M., van der Lende T., Taverne M.A.M. (2005). Factors affecting duration of the expulsive stage of parturition and piglet birth intervals in sows with uncomplicated, spontaneous farrowings. Theriogenology 64, 1573-1590.

Van Rens B.T.T.M., van der Lende T. (2004). Parturition in gilts: duration of farrowing, birth intervals and placenta expulsion in relation to maternal, piglet and placental traits. Theriogenology 62, 331-352.

Vanderhaeghe C., Dewulf J., Ribbens S., de Kruif A., Maes D. (2010). A cross-sectional study to collect risk factors associated with stillbirths in pig herds. Animal Reproduction Science 118, 62-68.

Vinsky M.D., Novak S. Dixon W.T., Dyck M.K., Foxcroft G.R.(2006). Nutritional restriction in lactating primiparous sows selectively affects female embryo survival and overall litter development. Reproduction, Fertility and Development 18, 347-355.

Vonnahme K.A., Wilson M.E., Ford S.P. (2002). Conceptus competition for uterine space: different strategies exhibited by the Meishan and Yorkshire pig. Journal of Animal Science 80, 1311-1316.

Walkiewicz A., Kasprzyk A., Babiez M. (2006). The influence of induced parturition in pregnancy and chemical composition of colostrum and milk in three successive reproduction cycles of gilts. Animal Science Papers and Reports 24 (1), 71-80.

Wehrend A., Stratmann N., Failing K., Bostedt H. (2005). Influence of Partus Induction on the $\mathrm{pH}$ Value in the Blood of Newborn Piglets. Journal of Veterinary Medicine A 52, 472-473.

White K.R., Anderson D.M., Bate L.A. (1996). Increasing piglet survival through an improved farrowing management protocol. Canadian Journal of Animal Science 76, 491-495.

Widowski T.M., Curtis S.E., Dziuk P.J., Wagner W.C., Sherwood O.D. (1990). Behavioral and endocrine responses of sows to prostaglandin $\mathrm{F}_{2 \alpha}$ and cloprostenol. Biology of Reproduction 43, 290-297.

Yang P-C., Fang W-D., Huang S-Y., Chung W-B., Hsu W.H. (1996). Farrowing induction with a combination of prostaglandin $\mathrm{F}_{2} \alpha$ and a peripherally acting $\alpha 2^{\text {-adrenergic }}$ agonist AGN 190851 and a combination of prostaglandin $\mathrm{F}_{2 \alpha}$ and oxytocin. Theriogenology 46, 1289-1293. 